\title{
Concepts of moral education in Poland
}

\begin{abstract}
In this article the author presents the contemporary understanding of the subject of moral education. Furthermore, he presents the historical development of the concept of moral education in Poland. He concludes that the current model of moral education in Poland was developed as early as the 18th century.
\end{abstract}

Stefan Konstańczak

Keywords: moral upbringing, moral education, history of moral education in Poland, concepts of moral education in Poland.

\section{Introduction}

Education is a specific sphere of human life. It cannot be limited only to the dimension of the individual as his being is a teacher-pupil relationship. The transfer of values from the teacher to the pupil is of particular importance since the teacher becomes a spokesman for society and equips others with knowledge and skills which are necessary for the pupil to become a useful member of a particular community. This process takes place on many levels including moral, aesthetic, health, physical, civil, and sexual (Zarzecki, 2012, p. 113). ${ }^{1}$ However, for society, moral education is of paramount importance because outside the intellectual sphere, the spheres of volition and emotion are shaped in the young generation.

The term "moral education" is not universally accepted in Polish pedagogical and philosophical literature. Parallel terms like "ethical education" and "value-based education" (Łobocki, 2006, pp. 11-12) exist with identical meanings. This emphasizes that, in principle, every educational process is related to moral education because during its course the pupil is both taught and drilled to observe the norms and values in a given society. Therefore, in Polish literature, two understandings of "moral education" exist which are used in a wider or narrower sense. When used in the wider sense, it is any educational process, since the essence of educational interaction is always the transfer of values and norms which prepare the pupil to live in society. The narrower meaning refers to formal education, which is performed with specific activities, especially during school lessons in subjects like 'Social Studies', 'Family Life' and 'Religious Education'.

The subject of moral education concerns not only each individual, but also whole social groups. Such a process is always focused on improving personality by raising pupils' moral level. Although everybody is subjected to such education, it is focused on the youngest generation. Moral education has a particular dimension in communities where rehabilitation is carried out; that is, educational activities, which once proved to be ineffective, are reintroduced. Thenceforth, there is an attempt to eliminate the failures which have primarily arisen during the natural course of moral education in the family. For this reason, one can say that moral education involves leading the pupil from a state of anomie to a level in which he will discover his own value and become a fully-fledged member of society (Hornowska,

\footnotetext{
${ }^{1}$ The spelling of all Polish quotations as in original.
} 
1938, pp. 166-169). The same task is performed both in the case of rehabilitation and upbringing in the family. However, in the case of young people, one can only talk about moral improvement, and therefore of multiplying moral values which they already hold.

According to Mieczysław Łobocki, moral education "is aimed, in particular, at the moral development of children and youth, especially to convey to them knowledge about moral problems and to develop in them skills to recognise what is bad, ignoble, or even despicable from a moral point of view. [ $\mathrm{I} \mathrm{t}$ teaches moral sensitivity and a readiness for moral conduct" (Łobocki, 2006, pp. 269). This type of definition is a generalisation of Polish historical experience relating to the implementation of institutional and non-institutional forms of moral education of the young generation.

\section{Moral education in Poland}

From the very beginning of institutionalised moral education, its relationship with religion and its practical dimension have been emphasised. "Virtue is a certain level of moral perfection in accordance with heavenly and earthly laws, i.e. it is the directing of the will by reason towards goodness. If one behaves in this way, one has good morals, fulfils one's obligations, and is morally good. On the other hand, misconduct, or in other words sin in the most general sense, is a defilement of both heavenly and earthly laws, i.e. deliberately directing the will towards evil. He, who behaves like this, has bad morals does not perform his obligations, and is morally bad" (Koncewicz, 1830, p. 1).

Even then the principal objective of moral education was to accustom pupils to fulfil obligations that were considered necessary for the formation of good character. These were responsibilities under three categories: to God, to oneself and to one's neighbour. The supremacy of moral education in the family environment over the school environment was also stressed. Only in the family environment is it possible to have such individualisation of upbringing, which in a diverse religious and social school environment was difficult (Forster, 1862, p. VIII).

However, formalised educational institutions only appeared in Poland late in the Middle Ages. They were then inextricably linked to educating the clergy. For centuries, a priest was most frequently the teacher who prepared his successors as well as the most privileged members of society. The main aim of teaching was thus to provide religious education to the spheres of decision-makers in the country. The acquired knowledge did not need to be practical; what was important was that the pupil became a permanent member of the Christian community. In the first Polish university, the Academy of Kraków, The Liberal Arts Department was the most important. Its alumni were to raise the moral condition of society as a whole to a higher level. The importance of this faculty to society was clearly expressed by Stanisław of Skarbimierz, when he wrote "This faculty deserves honour, praise and grace, because through it the honours of the Church and benefits for the Polish kingdom multiply; it enriches the body, makes the soul kinder and contributes to everything that the monarchy excels in; wisdom will scintillate through it, the entire community will be enriched, and dishonour will go into exile" (Rebeta, 1970, p. 24). Thus, the main task of The Liberal Arts Department was to educate the teaching cadre, who could guarantee to raise the moral and mental level of Polish society, and in the long term, to also raise the importance and power of the state.

However, it was the Renaissance that brought changes in the perception of the role of the teacher in the education of the young generation. One of the creators of the new perspective for this role was Szymon Marycjusz from Pilzno, the author of $O$ szkołach czyli akademiach ksiag dwoje (Marycjusz z Pilzna, 1955). His work was full of concern about educating citizens who will be useful to the state. School and public education were to help increase the power of the state and integrate the population. The teacher's task was therefore primarily to 
equip young people with knowledge and moral education, which at the same time was also to shape their responsibility for the state's future. Although everybody possesses the seeds of all the virtues, a teacher is, however, essential for their discovery and development. The role of the teacher is thus enriched with educational tasks, which are specially targeted at training students in virtue and in the ability to interact with others. It was not an easy task, because the work on the shaping of a person, who is fully responsible for the fate of the state, was hindered by the laziness and ignorance of those responsible for education (the clergy), and the complete indifference of the spheres of decision-makers (the nobility) to the problems of teaching and education.

Such a perception of moral education was also familiar to Andrzej Frycz-Modrzewski, one of the greatest thinkers of the Polish Renaissance. In his epochal work "On improving the Republic", one chapter (About school) was devoted to the problems of public education. The basic task which Frycz-Modrzewski placed before the teachers was moral education. Society as a whole, as well as every individual, must constantly improve morally. No one can be released from this responsibility because everybody should learn goodness and virtuous behaviour from childhood. The teacher should then teach ethics and accustom and train young people to practise virtue. Only in this way can the prosperity of the state and its citizens be ensured. Thus teaching becomes a political task. The bottom line is that it is the teacher who actually educates future kings, priests and judges, and therefore the prestige and importance of the entire state depends on his work.

From among those schools created during the Reformation, the grammar school in Leszno, founded by the Czech Brothers, deserves a special mention. When Johann Amos Comenius was its Rector between 1634 and 1641 he wrote his greatest work, "The Great Didactic". There is no doubt that it significantly affected Polish pedagogical thinking. According to Comenius, the whole world was a school, like a person's entire life. We are constantly learning, from the moment of our birth until death. The role of the teacher is first performed by our parents. "From the moment a person's formation begins it is necessary to keep watch that he does not undergo deformation and distortion. [...] So concern for children should arise earlier, before children are born" (Komeński, 1973, pp. 141-142). The School of Life constantly needs teachers. "Since throughout life it was necessary to learn to be truly wise, to speak, and act, then the highest degree of this knowledge should be: (1) a possession of sound wisdom - to get to know and correct the mistakes of one's life; (2) to speak honestly - to educate others with good advice; (3) to act honestly - to do only what is worthy of candidates for immortality. [...] Also disgraceful is the person who is only a dictionary, i.e. a storyteller without achievements in deeds" (Komeński, 1973, p. 278).

During the Enlightenment Period, reflection on the importance of moral education of the young generation underwent significant enrichment. Education ceased to be the domain of the church and became a national task over which the state slowly took control. The modern approach to education in Poland started with the creation of the National Education Commission (Komisja Edukacji Narodowej, KEN), the first European state and secular school authority.

The National Education Commission was established by a resolution, passed by the Polish Parliament (Sejm) in 1773. At that time there were widespread aspirations to rebuild the splendour of the country and to create a stable viable state organism. The road to attaining this goal was through shaping the national consciousness of the whole society. The National Education Commission pursued this goal and took over all education from the Jesuits, including their teachers and the huge wealth of the Order. The reform was to cover all education, including universities. As a result of these changes new training programs were developed, new teaching methods were introduced, and school books were adapted. The fundamental goal, to integrate Polish society into a single nation, was achieved particularly 
through the elimination of suspicions among classes, by awakening a passion for work, and by shaping patriotism and respect for all people, regardless of their financial status and origin (Suchodolski, 1980, p. 314).

The enormity of the tasks that fell on the teachers demanded from them primarily, their own exemplary behaviour which supported these goals. Since then, teachers have headed the most patriotic fractions of Polish society. Henceforth, moral teaching of the youth has become identified with its civil education. KEN stated that "one cannot exclude political responsibilities from moral teachings. Being as we are all sons of the motherland and volunteers of the movement, everyone should also know what obligations are required of them" (Suchodolski, 1980, p. 290). A special subject "moral teachings" was introduced, because it was recognised that the cause of the fall of the First Polish Republic was the result of deficiencies in legal knowledge and a lowering of moral standards in society.

This task was to be realised by teachers on all education levels. In an appropriate legal Act, KEN combined legal education with moral teaching and instructed schools this way: "The teacher lecturing on moral teachings must always instil good manners in the youth he is responsible for, so the youth should behave in accordance with the rules of humanity and justice, as all is dependent on good habit and custom, together with a sufficient explanation of duties" (Concise, 1925, p. 311).

The cause of the fall of the First Polish Republic for the contemporary intellectual elite was clear. It was the fall of moral standards, which manifested itself not only in the lawlessness of the nobility, but particularly in too little sense of social justice. The notorious practice of "Liberum veto", along with the slogan "A nobleman in the homestead is equal to a Voivode (Count)" led to the collapse of law in Poland. The reformers were convinced that it was the main cause of the state's failure and powerlessness. However, they realised that the education system was unable to complement the deficiencies in family education and thus a system of issuing Certificates of Morality became widespread, which were required from candidates for certain types of school. Representatives from the state and church were authorised to issue such certificates. The certificates confirmed that the given young person presents specific moral values and, therefore, was brought up in a family environment conducive to his development. Moral education in schools was then combined with education in law. To induce the conservatively orientated nobility to participate in this process, moral and religious education were combined. Such a system of moral education survived the final years of the Republic and was also implemented during the Partitions.

The teachers' tasks were then clearly and precisely defined by the state, which imposed on them an obligation to school the pupils in good manners and respect for the inherent dignity of the human being, in particular to prepare them for independent living, as well as to work and to serve the interests of the state. Teachers became responsible not only for overcoming class barriers and shaping pro-social attitudes, but also for eliminating moral defects such as lack of respect for themselves and others, pride, hypocrisy and falsehood in relation to the environment in both students and in themselves. The scope of obligations also includes selfimprovement, proper preparation for classes, and moreover extended to developing in students a pursuit of knowledge.

Such practices of moral education are reflected in textbooks on moral teachings which state that "morality and religion cannot be two different separate things, that one and the other must firstly be based on the revelation of the old Order, secondly on a renewed and a more clearly developed Christian revelation, that this revelation is by no means opposed to human reason, but there is a need for the reason and reality is based on it" (Dziekonski, 1831, p. 5).

However, the education slogans of the Enlightenment Period alone could not avert a looming political disaster. Loss of independence radically changed the perception of teachers' obligations in relation to education of the public. Romanticism also imprinted its mark on the 
theory of moral education. Its peak developmental achievement was Polish national philosophy, whose representative was Bronisław Trentowski, a supporter of radical modernisation of educational thought and practice. This philosophy was born from national roots and was to fulfil the tasks for the nation it served. Therefore, everybody's task is endless service to the motherland, to achieve public enlightenment and to lead the nation in fulfilling its historical task. Thus it was necessary to school everybody in the system of values appropriate to fulfilling such tasks. These values were expressed primarily to meet obligations. The obligation includes the highest ethical good and the highest benefit from life, i.e. self-satisfaction and honour, as received from other people (respect and worship). Thus the highest virtue is giving oneself into the service of one's neighbour. Every citizen has a duty to improve himself, but the teacher has an additional responsibility to serve the public by directing young people towards goodness. The teacher's task was therefore the formation of a creative personality, capable of transforming the world. This task will only be fulfilled if the teacher sees in the pupil an individual who is active, creative, independent and thoroughly prepared for life.

Trentowski paved the way for National Pedagogy, in which the principal meaning is attributed to moral upbringing. Henryk Rowid, a leading theoretician of this pedagogy, argued that "the Polish child's physical and spiritual welfare is the main task of the work; it is the wellbeing of an independent and united Poland, to be planted as an indivisible whole in the soul of every child" (Rowid, 1918, p. 1). The ideal of National Pedagogy combines "vocational education with broad horizons of thought, individual self-reliance with a high degree of socialising, physical health with fitness and spiritual balance, a capacity for initiative and moral fortitude, a sense of personal freedom combined with the civil movement". Teachers must also be prepared for this task as they are supposed to take care that every child should be able to "become a creative factor in social life". To meet the new challenges, teachers must not only possess pedagogical knowledge since "mentors need to be familiar with psychology, [...], as well as full of enthusiasm for bringing up others in a social, civil and national spirit" (Kretz-Mirski, 1921, p. 14).

National Pedagogy prepared Polish society to re-invent its own statehood. It became possible thanks to a program of moral education implemented consistently.

\section{The contribution of Polish science to the theory of moral education of the young generation}

In the interwar years Polish science was dominated by attitudes similar to the idea of clerisy, academic freedom identified with scientists distancing themselves from solving current political and social problems. The exception to this rule was Tadeusz Kotarbiński, who arrived at the University of Warsaw after its revival in 1918. However, the atmosphere of the conservative academic community did not suit his convictions. It was natural for a young professor at the University of Warsaw to involve himself in the activities of a liberal circle of intellectuals who were associated with the Polish Association of Free Thought (Polski Związek Wolnej Myśli, PZWM). It was an organisation which was in a kind of competition with the Association of Polish Freethinkers, but unlike it, was free of political conflicts and ideological involvement.

In PZWM's statute it was written:

d) "Polish Freethinkers, striving for truth through science, and to the good through ethics, demand from their supporters an active effort towards realising their ideals through human and cultural means. At the same time, they do not recognise as truth anything which opposes established scientific results, however they consider as good the selfless application into everyday life such moral principles, which are harmless, but which on the contrary, can bring a neighbour help and rescue. 
e) Polish Freethinkers are not content merely with their own views and philosophy for personal use, but as their moral obligation they consider promoting the Freethinkers' rules within their society, always trying to ensure that social life itself, in all its aspects, is based on the principles of reason and justice" (Trzy, 1935, p. 15).

Tadeusz Kotarbiński joined such a group. One can suppose that Kotarbiński must have exerted considerable influence on the final shape and content of the program documents of the Association. The Circle of Intellectuals issued an independent periodical 'Racjonalista' (The Rationalist) from October 1930. It must be remembered that Kotarbiński was President of the Warsaw Circle of Intellectuals of PZWM (cf. Komunikat, 1932, p. 177), and very often published his articles in the Circle's publications which commented on current events in the country. In the program declaration the Freethinkers proclaimed: "The Warsaw Circle of the Polish Association of Intellectuals of Free Thought wants for its members, particularly all those who are in solidarity with the needs of people working in spiritual culture, who intend to collaborate in the fight for freedom of speech, to eradicate all socially harmful attitudes and anti-rational doctrines from minds, particularly religious superstition and in the fight for secularisation of schools, marriage and all areas of public administration in general. [...]. The Circle does not consider the Freethinkers' activities justified as an exclusive co-tool in the fight for a fairer economic system, but sees in it a desire to defend spiritual wellbeing, threatened in the current conflicting systems of social ties" (Deklaracja, 1932, p. 34). It was not the only liberal organisation which brought together representatives of the Polish intelligentsia. The Polish intelligentsia maintained a progressive character during the interwar years which was also supported by organisations of freethinkers. They tried to spread their slogans among the young people, especially university students, in which they were quite successful.

At the same time, Polish neo-Thomistic education was also developing dynamically, independently of the actions of Polish rationalists. Particularly noteworthy are the innovative attempts by Jan Salamucha to logically justify Christian pedagogy. He presumed that moral education should not destroy that what had already been achieved, but should concentrate on improving it within the framework of theological thought. What is good must therefore be protected and not constantly changed. However, there are no steadfast rules to help achieve this since pedagogy is not a science analogous to mathematics. That is why faith is dominantly significant for Catholic education and always takes precedence over science (Salamucha, 1947, p. 483).

Science did not always set noble goals in relation to moral education. In the $19^{\text {th }}$ century, the eugenic movement in Poland was developing dynamically which, along with improving social health, promoted a new model of moral education. When Poland regained its independence the Polish Society of Eugenics (Polskie Towarzystwo Eugeniczne, PTE) set itself as a goal the defence of the regained independence understood in a specific way. In documents signed by the PTE from this period, the common recurring assertion is "a nation that has lost its independence is doomed" (Słoniowska, 2012, p. 60). Polish eugenicists believed that the Partitions will not to be repeated, being dependent on the health and morality of its citizens. At the same time, they acknowledged that both the size of the population, and the citizens' health were unsatisfactory, which seemed to be the aftermath of the Partitions. Therefore, much attention was paid to the elimination of social addictions, so-called racial poisons such as alcoholism, prostitution and venereal diseases. The way to achieve this goal was through moral renewal, which was to be accompanied by an improvement in the health of the whole population. Indeed, the eugenicists believed that moral condition is secondary to physical condition, and thus the path to moral renewal was through improving living conditions and the health of Polish society. 
The PTE, in its heyday during the interwar years had 26 eugenic clinics. There were seventeen regional branches, and the Society consisted of several sections. The clinics dealt primarily with mother and child care, the fight against sexually transmitted diseases, as well as conducting research into social pathology. It also carried out preventive activities within the prophylactic and treatment section. There was even a section that dealt with sex education and ethics, which dealt with birth control and infertility treatment (Słoniowska, 2012, p. 64). Within its framework, pioneering lectures on contraception were also carried out, which were met with criticism from conservative organisations and institutions. However, Polish eugenicists, unlike their German counterparts, did not propagate racism and never placed a value on people based on their suitability for a "healthy" society.

The upcoming war did not attract supporters for eugenics. The Nazi Aktion T4 put into practice the theory of racial hygiene, physically eliminating from society all those who from the top were deemed to be of low value, unsuitable and who spoiled the race. Despite the traumatic experiences of World War II, after the war there were attempts to revive the organised eugenic movement in Poland, but they were unsuccessful.

\section{Moral education after World War II}

The permanent presence of national and public education in Polish pedagogy was confirmed throughout the Nazi occupation, during which its foundations were used to create a curriculum and a nurturing program in the underground teaching system, the so-called secret education. National and pro-state elements helped to protect Polish youth from mental degradation and denationalisation. On account of this secret education, continuity in the educational system in Poland was preserved, thanks to which after the war an almost immediate launch of institutional education for the young generation was possible.

Post-war reality was not conducive to the development of indigenous pedagogical and philosophical reflection. Attempts were made to introduce formulas directly borrowed from the then Soviet Union, where moral education was largely ideological. Political ideology resulted in the removal of experienced teaching staff, with their roots in the interwar years, depriving them of influencing educational transformations. However, most damaging turned out to be generation discontinuity in the teaching of moral education. Thence, all the achievements of theoreticians of moral education in the interwar years were nullified. New orders relating to moral education were determined by the ideological declarations: "No dredging up the relics of the bourgeois consciousness, without combating bourgeois political, legal, moral, philosophical, aesthetic views, without a victory of new ideas and without permanently strengthening new institutions in response to the needs of the socialist base, in a nutshell, without a permanent development of socialist consciousness a socialist nation cannot eventually be created. Hence, from this result the basic tasks of philosophy in Poland. [...] Therefore, we must fight for an overall victory of this philosophy for the masses, for its total control of the minds of the creative intelligentsia, and for its further development and prosperity" (Schaff, 1956, p. 96).

Defence of the interwar system of values was impossible, new methods of moral education were forcibly introduced into the school system. For the old staff, only memories full of bitterness remained: "But one became bitter at the thought that it was ending like this, and that continuity of a particular way of thought is being broken, that one is unable to hand over into young hands the torch which has been passed on for years" (Dąmbska, 1952, p. 34). However, this does not mean that former mentors gave up without a fight. Even in times of severe Stalinism they were able to use common sense and accurately evaluate new orders: "This is probably the hardest that under the old words "truth", "freedom", "justice", etc. an antonym has been underlaid and used as if denoting the same thing. And that people are forced to, or at least attempts are made to force them to, reveal beliefs and feelings contrary to those that they 
have. And that one does not serve education, but education is to serve the party and politics. A new dogmatism of some new metaphysics and new methods are promoted. Some gloomy Godless religion; << Philosophia ancilla tyranidis $>$. It hurts. And how right you are Professor, that it is tasteless even to say those things that one considers true if saying other things is forbidden" (Dąmbska, 1949, pp. 14-15). The Polish intelligentsia was during this period effectively silenced.

The Polish intelligentsia, especially teachers, who were always orientated patriotically with a mission to raise moral culture in society, found themselves trapped in the previous commitment. They did not want to return to the past, but were unable to create an attractive vision of the future which could compete with Marxism. This schizophrenic situation of the contemporary intellectual elite is well documented in Leopold Tyrmand's "Diaries", in which he explained the attitude of people from the worlds of culture and science rather curiously: "Classy and national discord with some principle, which one is tormented by, but which effectively wraps itself in the velvet of traditional refinement of minds and feelings. Their life is governed by the Concept - a recipe for Poland in a new system including positive communism and prospects of Catholicism in current geopolitics, history, historicism, old bourgeois-liberal finesse, the eternal rules of the game in new packaging made of LeninistStalinist plastics. For me it is a lucrative collaboration not deprived of its grace, for them it is a Concept with a sophisticated smile which so flawlessly and with such sophistication blurs the outline of the truth, that in the end one does not know if by accident it is an honest ideological impulse. The Communists recognise the importance of quoting highly regarded Polish names and are willing to pay well for permission to attribute 'Catholic' statements to these people which taste like jokes in the theatre of the absurd"' (Tyrmand, 1989, p. 50).

However, Tadeusz Kotarbiński was the most influential due to his public position. He was treated by Marxists as a kind of a difficult ally, who at least partly shared their views. Kotarbiński did not care only for developing the concept of independent ethics, but as a true social worker he also wanted to popularise it, and the Society for Moral Culture (Towarzystwo Kultury Moralnej, TKM) was to serve his purpose. However, the Society's work did not attract many supporters, just the opposite. In the absence of independent organisations the TKM created a semblance for action for all kinds of political opposition. Within this organisation, Władysław Bieńkowski, the first Polish political dissident, also worked and even became a manager, perhaps only realising in this way his unfulfilled political ambitions. However, the authorities did not tolerate any competition and the fate of the TKM was thus sealed.

\section{Conclusion}

Since the period of political transformation, which has taken place in Poland since 1989, economic debates have dominated mass media which have pushed the problem of moral education into the background. The new governing team, which replaced the former communist nomenclature, assumed that the problem will be solved by introducing religious education into schools. However, the restoration of religious education revealed problems that previously did not exist, or at least had no opportunity to appear. The problem is related to children and young people from religious minorities as well as atheists. It is paradoxical, but current moral education is confined only to religious education, as if it favours the disintegration of society, exposing its differences, and not what is common. Currently in Poland two trends have emerged as to how to achieve the objectives of moral education. The first one calls upon proven traditions, and so tries to revive the well-known standards of the past, which allowed the Polish nation to survive hard times during the partitions. These are standards of moral education introduced by the Commission for National Education. The second trend would like to introduce models that refer to universalism, which in turn results in 
attempts to base moral education on the idea of multiculturalism, which in the current political situation in the world, and especially in Europe, has little chance of success. The currently implemented model of moral education in Poland is a traditional model and enjoys the support of the majority of society. The second model has been discredited, in particular by a wave of economic migrants, of over two million Polish citizens, who easily assimilated themselves into the societies of the countries in which they reside and thus have significantly weakened Polish society. But in any organised education, it is not about preparing the young generation to enrich others, but to boost to the maximum one's own capabilities and integrate one's own citizens around shared values.

Stefan Konstańczak - Chairman of the ethics section of the Institute of Philosophy at the University of Zielona Gora, Member of the Committee of Philosophical Sciences of the Polish Academy of Sciences

\section{Corresponding author:}

Stefan Konstańczak, Uniwersytet Zielonogórski, Instytut Filozofii, Al. Wojska Polskiego 71A, 65-762 Zielona Góra, Poland

email: S.Konstanczak@ifil.uz.zgora.pl

\section{References}

DĄMBSKA, I. (1949): List Izydory Dąmbskiej do Tadeusza Kotarbińskiego z 12 lipca.1949 r. [A letter from Izydora Dąmbska to Tadeusz Kotarbiński dated 12. July.1949]. In: Archiwum Połaczonych Bibliotek WFiS UW, IFiS PAN i PTF w Warszawie, Rps U 598, vol. 6, pp. 1415.

DĄMBSKA, I. (1952): List Izydory Dąmbskiej do Tadeusza Kotarbińskiego z 3. X.1952 r. [A letter from Izydora Dąmbska to Tadeusz Kotarbiński dated 5.Oct.1952]. In: Archiwum Połaczonych Bibliotek WFiS UW, IFiS PAN i PTF w Warszawie, Rps U 598, vol. 6, p. 34.

DEKLARACJA [Declaration] (1932): In: Racjonalista, No. 3, p. 34.

DZIEKOŃSKI, T. (1831): Nauka moralna o powinnościach względem bliźniego [Moral teaching related to duties to others], part III. Warszawa.

FORSTER, K. (1862): Do matek Polek [To Polish Mothers]. In: P. Janet (ed.): Rodzina: Lekcye filozofii moralnej [Family: Lessons of moral philosophy]. Berlin: Księgarnia B. Berhra (E. Bock), pp. v-x.

HORNOWSKA, M. (1928): Alkoholizm jako zagadnienie wychowania moralnego [Alcoholism as an aspect of moral education]. In: Alkohologia. Warszawa: Polskie Towarzystwo Walki z Alkoholizmem, pp. 167-186.

KOMEŃSKI, J. A. (1973): Pampaedia. Wrocław: Ossolineum.

KOMUNIKAT [Statement] (1932): In: Racjonalista, 12, p. 177.

KONCEWICZ, L. (1830): Nauka moralna o powinnościach człowieka względem samego siebie ułożona dla użytku klass wyższych szkót wojewódzkich [Moral education related to Man's duties to oneself for the higher classes in provincial schools]. Warszawa: W drukarni Piiarów.

ŁOBOCKI, M. (2006): Wychowanie moralne w zarysie [Moral education in brief]. Krakow: Oficyna Wydawnicza „Impuls”.

KRETZ-MIRSKI, J. (1921): Szkoła wychowawcza [Educational School]. In: Ruch Pedagogiczny, 4-5, pp. 1-14.

MARYCJUSZ z PILZNA, Sz. (1955): O szkołach czyli akademiach ksiag dwoje [About schools that is academies - two books]. Wrocław: Ossolineum. 
PODRĘCZNA ENCYKLOPEDIA PEDAGOGICZNA [Concise Education Encyclopedia], vol. 2, Lwów-Warszawa: Książnica Polska.

REBETA, J. (1970): Komentarz Pawła z Wroczyna do Etyki Nikomachejskiej [Pawet from Wroczyn Comments on Nicomachean Ethics]. Wrocław: Ossolineum.

ROWID, H. (1918): Nowa era wychowania narodowego [New era of national education]. In: Ruch Pedagogiczny, 1, pp. 1-2.

SALAMUCHA, J. (1947): O katolicką kulturę intelektualną [About the Catholic intellectual culture]. In: Znak, 2(5), pp. 481-489.

SCHAFF, A. (1956): Aktualne zagadnienia polityki kulturalnej $w$ dziedzinie filozofii $i$ socjologii [Current issues related to cultural politics in philosophy and sociology]. Warszawa: PWN.

SŁONIOWSKA, A. (2012): Recepcja i rozwój idei eugenicznej na ziemiach polskich w XIX i XX wieku [Reception and development of the eugenic idea in Poland in the 19th and 20th Century]. In: Studia Ecologiae et Bioethicae", 4, pp. 53-72.

SUCHODOLSKI, B. (1980): Dzieje kultury polskiej [History of Polish culture]. Warszawa: Interpress.

TRZY deklaracje Polskiego Związku Myśli Wolnej przyjęte przez I Ogólnopolski Zjazd delegatów Związku w dniu 29-go grudnia 1929 r. w Warszawie [Three Declarations of Polish Association of Free Thought accepted by the 1st National Convention for Delegates on 29th December 1929 in Warsaw]. In: Kalendarz wolnego myśliciela 1935/36 [The Freethinker's Diary 1935/36]. Warszawa: „Wolnomyśliciel Polski”.

TYRMAND, L. (1989): Dziennik 1954 [Diary 1954]. Warszawa: Res Publica.

ZARZECKI, L. (2012): Teoretyczne podstawy wychowania. Teoria i praktyka $w$ zarysie [Theoretical basis of education.Theory and practice in brief]. Jelenia Góra: Karkonoska Państwowa Szkoła Wyższa. 